\title{
The Investigation on Cholinesterases and BACE1 Inhibitory Activities in Various Tea Infusions ${ }^{\dagger}$
}

\author{
Uthaiwan SUTTISANSANEE*, Thanit KUNKEAW, \\ Natthaphon THATSANASUWAN, Jutamat TONGLIM and \\ Piya TEMVIRIYANUKUL
}

\author{
Institute of Nutrition, Mahidol University, Phutthamonthon, Nakhon Pathom 73170, Thailand
}

('Corresponding author’s e-mail: uthaiwan.sut@mahidol.ac.th)

Received: 31 March 2018 Revised: 17 July 2018, Accepted: 26 August 2018

\begin{abstract}
Alzheimer's disease (AD) is a chronic neurological disease related to the decline in brain and nervous system functions. At present, inhibitions of cholinesterases (ChEs) including acetylcholinesterase $(\mathrm{AChE})$ and butyrylcholinesterase $(\mathrm{BChE})$ to enhance neurotransmitters and retardation of $\beta$-amyloid formation through $\beta$-secretase (BACE1) inhibition are 2 hypotheses for AD prevention and treatment. Hence, this study aims to investigate inhibitory activities against ChEs of various tea varieties of Camellia sinensis and herbal teas. At this step, the screening methodology for ChEs inhibitory activities in various tea varieties in order to provide a fast, inexpensive and convenient method for the detection of anti-cholinesterase activity was optimized. Then, selected tea with high ChEs was further examined regarding its BACE1 activity. As results, all tea samples displayed both anti-AChE and -BChE activities with the broad ranges of $6-85 \%$ and $0-72 \%$ inhibitory activities, respectively. Interestingly, $C$. sinensis teas exhibited higher ChEs inhibitory activities than herbal teas, in exception of Pandanus amaryllifolius (pandan) tea, which exhibited comparable inhibitory activities as $C$. sinensis teas. Pandan leaves were found to exhibit anti-BACE1 activity with $98 \%$ inhibition. Besides, preliminary in vivo study showed that pandan leaves extract was able to rescue climbing defect observed in AD Drosophila melanogaster model, indicating the potential roles of pandan leaves in $\mathrm{AD}$ prevention.
\end{abstract}

Keywords: Alzheimer's disease, anti-cholinesterase activities, assay conditions, Drosophila melanogaster, tea infusion

\section{Introduction}

Alzheimer's disease (AD) is a chronic degenerative neurological disease characterized by several symptoms including loss of memory, cognitive dysfunction, disorientation and behavioral disturbances. Various hypothesized pathways of AD occurrence that have been widely investigated and are the models for $\mathrm{AD}$ drug development are decrease of cholinergic synapses and $\beta$-amyloid formation. The cholinergic hypothesis is caused by decreasing forebrain cholinergic neurons and level of neurotransmitter carrying messages in the brain, acetylcholine (ACh) [1,2]. This neurotransmitter is located in hippocampus, the brain responsible for memory, and cerebral cortex, the brain area for thinking and making decision. Activity of $\mathrm{ACh}$ can be terminated by cholinesterases, including acetylcholinesterase (AChE) and butyrylcholinesterase $(\mathrm{BChE})$, the enzymes that hydrolyze $\mathrm{ACh}$ into inactive metabolites, choline and acetyl-CoA [1,2]. Likewise, hypothesis on $\beta$-amyloid formation is emphasized on $\beta$-secretase (also

\footnotetext{
${ }^{\dagger}$ Presented at the International Conference on Biomedical Sciences 2018: March 22 ${ }^{\text {nd }}-23^{\text {rd }}, 2018$
} 
known as $\beta$-site amyloid precursor protein (APP) cleaving enzyme1 or BACE1), the key enzyme that hydrolyzes APP and produces insoluble $\beta$-amyloid peptides. These peptides are toxic on dementia brain, since they can disrupt cell-to-cell communication, leading to death of neurons in the brain [3]. Besides, increased $\mathrm{AChE}$ and $\mathrm{BChE}$ are detected in the neuritic plaques in $\beta$-amyloid formation in the early stages of $\mathrm{AD}$, suggesting the relation among these hypotheses [4]. Therefore, the activation of the cholinergic function via the inhibition of cholinesterase enzyme and the decrease in $\beta$-amyloid plague via the inhibition of BACE1 may be proven to be helpful in terms of prevention and treatment of AD.

Tea polyphenols have been found to possess neuroprotective effect, which can protect brain cells from onset of $\mathrm{AD}$ and related disorders [5]. In vitro anti-cholinesterase activity of Camellia sinensis extract had previously been reported with the results showing that green and black teas were able to inactivate AChE and BChE [6]. Despite of C. sinensis teas being widely investigated, none have been reported on Thai herbal teas. Thus, the aim of this study was to investigate anti-ChEs activities of Thai herbal teas in comparison to $C$. sinensis teas using rapid calorimetric spectrophotometry. Based on the established protocol of ChEs assay by Ellman et al. [7] and Jung et al. [8], suitable enzyme and substrate concentrations must be determined to optimize assay conditions in prior of determining inhibitory activities. The major factors affecting the optimization process are 1) suitable enzyme concentration using time- and dose-dependent absorbance changes and 2) suitable substrate concentration using enzyme kinetics. Then, Thai herbal tea with the highest anti-ChEs activity was chosen for further investigation on $\beta$-amyloid formation, both in in vitro BACE1 inhibition and in vivo AD Drosophila melanogaster model. The information received from this study will be the first report on anti-AD properties of Thai herbal teas and is useful for potential development of functional drink with anti-AD properties and even AD drug design from anti-AD agents.

\section{Materials and methods}

\section{Sample preparation and extraction}

High quality of 5 varieties of conventional teas $(C$. sinensis) including green tea, white tea, black tea, oolong tea and pu-erh tea and 15 Thai herbal teas including bael fruit (Aegle marmelos (L.) Corr.), Indian gooseberry (Phyllanthus emblica L.), bitter cucumber (Momordica charantia Linn.), rosella (Hibiscus sabdariffa L.), safflower (Carthamu stinctorius L.), chrysanthemum (Chrysanthemum indicum L.), white mulberry (Morus alba L.), Asiatic pennywort (Centella asiatica (L.) Urban), pandanus (Pandanus amaryllifolius Roxb.), jiaogulan (Gynostemma pentaphyllum (Thunb.) Mak.), stevia (Stevia rebaudiana Bertoni), cat's whisker (Orthosiphon aristatus (Blume) Miq), lemon grass (Cymbopogon citrates (DC.) Stapf), jewel vine (Derris scandens Benth.) and ginger (Zingiber officinale Roscoe) approved by the Thailand Food and Drug Administration (FDA) were used in this study. Fresh pandan leaves (50 - $60 \mathrm{~cm}$ in length $\times 3-4 \mathrm{~cm}$ in width) were collected in October, 2013 from Phrae province, Thailand. The color of pandan fresh leaves was analyzed using a ColorFlex EZ spectrophotometer from Hunter Associates Laboratory, Inc. (Reston, VA, USA).

All samples were freeze-dried using a freeze dryer (Heto Power Dry PL9000, Thermo Fisher Scientific, Waltham, MA, USA) before grinding into fine powder by a cyclotec sample mill (series 1903 with $200-240 \mathrm{~V}$ and 50/60 Hz; FOSS, Höganäs, Sweden). The moisture content was determined using Association of Official Analytical Chemists (AOAC) method 930.15 (AOAC, 2005) before keeping dry samples in vacuum bags and storing at $-20^{\circ} \mathrm{C}$.

Tea samples ( $1 \mathrm{~g}$ dried basis) were extracted with $\mathrm{dH}_{2} \mathrm{O}(100 \mathrm{~mL})$ at $95{ }^{\circ} \mathrm{C}$ for $5 \mathrm{~min}$. All the extracts were then filtered through Whatman No. 1 filter paper and stored at $4{ }^{\circ} \mathrm{C}$ until use. Pandan leaves powder was extracted with deionized water (solid-to-liquid ratio of $1: 20 \mathrm{w} / \mathrm{v}$ ) at $30{ }^{\circ} \mathrm{C}$ for $15 \mathrm{~min}$ using a temperature-controlled water bath shaker (Memmert $\mathrm{GmbH}$, Wisconsin, USA). The mixture was then centrifuged at $1190 \mathrm{xg}$ for $10 \mathrm{~min}$. The supernatant was collected and filtered through Whatman No. 1 filter paper. The filtrate was then kept at $4{ }^{\circ} \mathrm{C}$ for analysis. 


\section{Optimization of cholinesterase assay}

High throughput screening methodology for cholinesterase inhibitory activity was developed through the use of cholinesterase assay. The assay involved the activity of cholinesterase reaction, performed by modifying a well-established protocol [7,8] with slight modifications as follows. The enzymatic reaction involved a colorimetric coupled assay between $\mathrm{ChEs}$ and 5,5'-dithiobis(2nitrobenzoic acid) (DTNB). The reaction mixture consisted of cholinesterase (Electrophorus electricus $\mathrm{AChE}(1,000$ units/mg) or equine serum BChE ( $\geq 10$ units/mg protein)), thiocholine (acetylthiocholine (ATCh) or butyrylthiocholine $(\mathrm{BTCh}))$ and DTNB $(16 \mathrm{mM})$. All chemicals were received from SigmaAldrich (St. Louis, MO, USA). The enzyme activity of the reaction mixtures was monitored at a wavelength of $412 \mathrm{~nm}$ by a microplate reader (BioTek Instruments, Inc., Winooski, VT) and Gen5 data analysis software. The initial rate was fitted by the Michaelis-Menten equation with least squares fit parameter by the GraphPad Prism software version 5.00 (GraphPad Software, Inc., La Jolla, CA).

Optimization of suitable enzyme concentration was determined by monitoring the change in timeand dose- dependent absorbance. The assay mixtures were prepared as mentioned above. The substrate concentrations, ACTh $(0.08 \mathrm{mM})$ and BCTh $(0.1 \mathrm{mM})$, were fixed, while the enzyme concentrations of $\mathrm{AChE}(5-310 \mathrm{ng})$ and BChE (3 - $500 \mathrm{ng})$ were varied. The enzyme activity was read at a wavelength of $412 \mathrm{~nm}$ by the microplate reader at room temperature.

Enzyme kinetics was investigated in order to determine the suitable substrate concentration. The substrates, ATCh and BTCh, ranged between 40 to $600 \mu \mathrm{M}$ were mixed with AChE $(10-30 \mathrm{ng})$ and $\mathrm{BChE}(10-50 \mathrm{ng})$, respectively. The enzymatic activity of reaction mixtures was then monitored at the wavelength of $412 \mathrm{~nm}$ by the microplate reader at room temperature.

\section{Cholinesterase inhibitory assay}

The inhibitory enzyme assay was performed on 20 tea infusions according to the above protocol using suitable enzyme (5 - $20 \mathrm{ng} \mathrm{AChE}$ or 10 - $50 \mathrm{ng} \mathrm{BChE})$ and substrate concentrations $(0.08 \mathrm{mM}$ ATCh or $0.1 \mathrm{mM} \mathrm{BTCh).} \mathrm{The} \mathrm{enzyme} \mathrm{inhibitory} \mathrm{activity} \mathrm{was} \mathrm{calculated} \mathrm{as} \mathrm{percentage} \mathrm{of} \mathrm{inhibition} \mathrm{using}$ the following equation; \% inhibition $=100 \times[1-((B-b) /(A-a))]$, where $A$ represented the initial velocity of the control reaction (without the extract) with the enzyme, $a$ represented the initial velocity of the control reaction without the enzyme, $B$ represented the initial velocity of the enzyme reaction with the extract and $b$ represented the initial velocity of the reaction with the extract but without the enzyme. Eserine, a reversible anti-cholinesterase drug, was used as a control inhibitor for both AChE and BChE assays.

\section{$\beta$-Secretase inhibitory assay}

The BACE1 inhibitory assay was performed on pandan leaves extract, which was choosing from the herbal tea infusion with the highest cholinesterase inhibitory activity screening from the previous experiment. This method employed a $\beta$-secretase (BACE1) Activity Detection Kit (Fluorescent) from Sigma-Aldrich (St. Louis, MO, USA). All reactions were performed using the 96-well microplate reader and monitored at an excitation wavelength of $320 \mathrm{~nm}$ and an emission wavelength of $405 \mathrm{~nm}$. The inhibitory activity was calculated as percentage of inhibition using the following equation; $\%$ inhibition = $100 \times[1-((D-d) /(C-c))]$, where $C$ represented the absorbance of the control reaction (without the extract) with the enzyme, $c$ represented the absorbance of the control reaction without the enzyme, $D$ represented the absorbance of the enzyme reaction with the extract and $d$ represented the absorbance of the reaction with the extract but without the enzyme.

\section{Locomotive assay}

Locomotive assay was performed on pandan leaves extract, which was choosing from the herbal tea infusion with the highest cholinesterase inhibitory activity screening from the previous anti-cholinesterase assays. To determine Drosophila climbing behavior, the trans-heterozygous flies from UAS-human amyloid beta-42 (BL32037) crossed with a neuron-specific driver (Elav, BL8640) were used in the assay as previously described [8]. These flies were specifically expressed human amyloid beta-42 in neuron cells, mimicking human AD pathogenesis. One day after eclosion, flies were fed with pandan extract at 
http://wjst.wu.ac.th

the concentration of $50 \mathrm{mg} / \mathrm{mL}$ before being cultured at $25^{\circ} \mathrm{C}$. Donepezil was also included as an AD drug control, and medium was replaced every 3 days. At day 7, 14 and 21, flies were transferred into a clean tube without anaesthesia. To initiate the experiment, the flies were collected at the bottom of the tubes by tapping the tube several times. After 30 seconds of waiting, the number of the fries that climbed up the tube wall at particular distance was collected. The climbing index of each group was calculated as follows: the sum of the number of flies in each score (related to the distance the fries were climbing up) multiplied by the score that they reached and then divided by the total number of flies in each group. Each experiment was repeated for 5 times.

\section{Statistical analysis}

All experiments were carried out in triplicates $(n=3)$. The data were expressed as mean \pm standard deviation (SD). One way analysis of variance (ANOVA) and Duncan's Multiple Range Test were performed to determine the significant differences between values. Probability value of $<0.05$ was considered as significant.

\section{Results and discussion}

\section{Optimized ChEs assay conditions}

Various methods have been used for the determination of cholinesterase inhibitory activity such as manometric, potentiometric, titrimetric, fluorometric, photometric, mass spectrometry, radioisotopic, polarographic and biosensors. However, the most widely used methods are radiometry, $\mathrm{pH}$-stat, electrometry and colorimetry. In addition, colorimetric assay utilizing Ellman reagent is one of the efficient technique for the determination of cholinesterase activity, as it can be modified for assessment of biological samples and wide scale experiments. Study of Ellman et al. [7] was focused on rapid colorimetric assay for the determination of AChE activity in blood samples, tissue extracts and homogenates. Another study conducted by Jung et al. [8] used spectrophotometric method for inspecting ChE inhibitory activities in Coptidis Rhizoma alkaloids.

The desirable enzyme concentrations and reaction times of $\mathrm{AChE}$ and $\mathrm{BChE}$ were determined using ATCh and BTCh, respectively, as the substrate analogues. The reaction rate was elevated with increasing enzyme concentrations and became plateau after a certain period of time when no more substrate was available (Figure 1). The suitable enzyme concentration for inhibitory assay is defined as the concentration that allows the steady initial reaction rate to be observed for a suitable period of time. According to our results, the time- and dose- dependent assays suggested that the active enzyme concentrations were approximately 10 - 30 ng for AChE and 10 - $50 \mathrm{ng}$ for BChE. For the reaction times, both the cholinesterase reactions could be detected within $20 \mathrm{~min}$, the time period that allows the linearity of the initial rate.

A

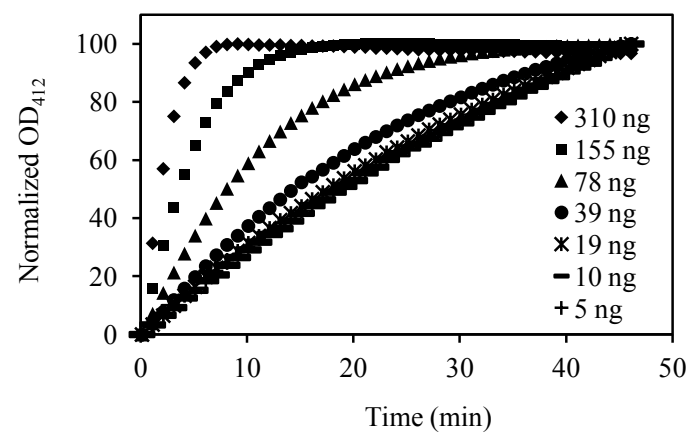

B

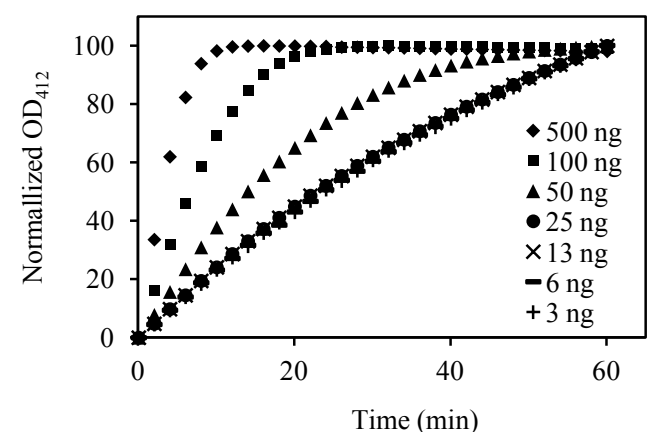

Figure 1 The time-dependent assays of (A) AChE (5 - $310 \mathrm{ng})$ and (B) BChE (3 - $500 \mathrm{ng})$ reactions using $0.08 \mathrm{mM}$ ATCh and $0.1 \mathrm{mM} \mathrm{BTCh}$, respectively, as the substrate analogues were prepared to determine desirable enzyme concentrations for the optimization of assay conditions. 
http://wjst.wu.ac.th

The enzyme kinetics of AChE and BChE were investigated in order to determine suitable substrate concentrations for the enzymatic assays (Figure 2). According to the study of enzyme kinetics, $K_{m}$ (Michaelis constant) value is defined as the substrate concentration at half of the maximum rate $\left(V_{\max } / 2\right)$. Thus, suitable substrate concentration should be within a close range of $K_{m}$ value in order to allow the steady initial reaction rate to be observed under a suitable period of time. In our experiment, it was found that the $K_{m}$ of AChE was $0.075 \mathrm{mM}$ and of BChE was $0.061 \mathrm{mM}$ under studied conditions. Therefore, the appropriate substrate concentrations (close to the $K_{m}$ values) were further studied. In the case of inhibitory assay of tea extracts, the substrate concentration of $0.08 \mathrm{mM}$ ATCh and $0.1 \mathrm{mM}$ BTCh for AChE and $\mathrm{BChE}$ assays, respectively, were used in reaction mixtures.

Eserine, a reversible anti-cholinesterase drug, was prepared as a positive control for ChEs assays. In our experiment, it was found that eserine could competitively inhibit cholinesterase with an inhibitory constant $\left(K_{i}\right)$ of $144 \mathrm{nM}$ for AChE and $305 \mathrm{nM}$ for BChE reactions. As well, $\mathrm{IC}_{50}$ of eserine for AChE was $0.41 \mu \mathrm{M}$ and that for $\mathrm{BChE}$ was $0.64 \mu \mathrm{M}$. These results suggested that eserine is a better inhibitor for $\mathrm{AChE}$ than $\mathrm{BChE}$ reactions. The relation between the concentration of eserine and enzyme inhibition could be used as a standard curve for further comparison with the degree of inhibition of tea extracts.

A

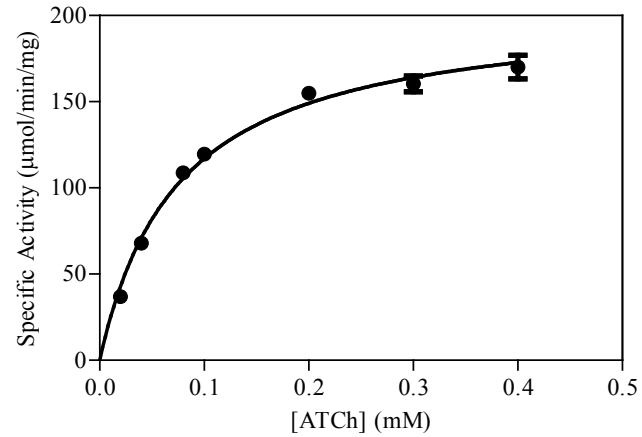

B

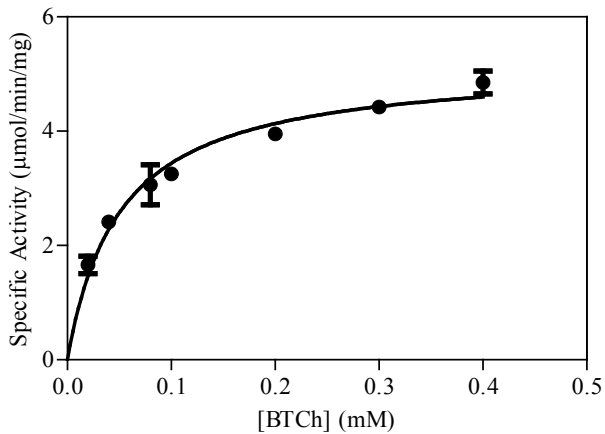

Figure 2 The enzyme kinetics of (A) AChE (10 - $50 \mathrm{ng})$ and (B) BChE (10 - $50 \mathrm{ng})$ that were prepared using different concentrations $(0.02-0.4 \mathrm{mM})$ of ATCh and BTCh, respectively, as substrate analogues.

\section{Cholinesterase inhibitory activity}

Based on this modified protocol, the rapid colorimetric spectrophotometry was used to obtain in vitro screening of anti-ChEs activities of conventional and Thai herbal teas (Table 1 and Figure 3). As results, high AChE inhibitory activities of all conventional tea infusions could be compared with eserine, in which AChE inhibitory activities of all conventional tea infusions were compatible to $0.89-1.00 \mu \mathrm{M}$ of eserine. These concentrations were greater than the $\mathrm{IC}_{50}$ of eserine $(0.41 \mu \mathrm{M})$ by $2.2-2.4$ folds, suggesting that conventional tea infusions could be effective sources of anti-AChE agents. However, herbal tea infusions exhibited lower anti-AChE activities (approx. 6 - $61 \%$ inhibition at the concentration of $2 \mathrm{mg} / \mathrm{mL}$ ), which were comparable to eserine at the concentrations of $0.03-0.47 \mu \mathrm{M}$. These concentrations were lower than the $\mathrm{IC}_{50}$ of eserine by $0.9-13.7$ folds. Pandan tea was found to exhibit the highest AChE inhibition, while cat's whisker and ginger teas exhibited the lowest.

For BChE inhibitory reactions, white tea infusion exhibited the highest inhibition, followed by green tea black tea, oolong tea and pu-erh tea, respectively (24-72\% inhibition at the concentration of 2 $\mathrm{mg} / \mathrm{mL}$ or approx. $0.12-0.67 \mu \mathrm{M}$ of eserine) (Table 1 and Figure 3). These results suggested that the order of inhibitory activity might be affected by the tea fermentation process, which has an effect on the quantity of bioactive compounds as being previously reported by Karori et al. [10]. Interestingly, some bioactive compounds such as antioxidants (e.g. ginkgo biloba, idebenone and selegiline), vitamin E, estrogen and non-competitive antagonist (e.g. memantine) were found to have a neuroprotective function 
http://wjst.wu.ac.th

towards the delaying of $\mathrm{AD}$ onset [11]. Thus, decrease in the quantity of extracted antioxidants could affect the inhibitory function against BChE. Likewise, Thai herbal tea infusions exhibited broad range of anti-BChE activities (approx. $1-48 \%$ inhibition at the concentration of $2 \mathrm{mg} / \mathrm{mL}$ ), which were comparable to eserine at the concentrations of $0-0.32 \mu \mathrm{M}$ (Table 1 and Figure 3). Pandan tea exhibited the highest anti-BChE activity, which was even higher than some conventional teas (oolong and pu-erh teas).

Table 1 The percentage of $\mathrm{AChE}$ and $\mathrm{BChE}$ inhibitions and their corresponded eserine equivalents of tea infusions.

\begin{tabular}{|c|c|c|c|c|c|}
\hline \multirow[b]{2}{*}{ Types } & \multirow[b]{2}{*}{ Tea infusions } & \multicolumn{2}{|c|}{ AChE } & \multicolumn{2}{|c|}{ BChE } \\
\hline & & $\%$ Inhibition $^{1}$ & $\begin{array}{c}\text { Eserine eq. }{ }^{2} \\
(\mu \mathrm{M})\end{array}$ & $\%$ Inhibition $^{1}$ & $\begin{array}{c}\text { Eserine eq. }{ }^{2} \\
(\mu \mathrm{M})\end{array}$ \\
\hline \multirow{5}{*}{$\begin{array}{l}\text { Camellia } \\
\text { sinensis }\end{array}$} & Pu-erh tea & $85.13 \pm 1.39$ & 0.99 & $23.91 \pm 2.30$ & 0.12 \\
\hline & Black tea & $85.33 \pm 4.06$ & 1.00 & $61.48 \pm 1.41$ & 0.49 \\
\hline & Oolong tea & $77.50 \pm 3.45$ & 0.78 & $43.92 \pm 0.93$ & 0.28 \\
\hline & White tea & $84.50 \pm 1.96$ & 0.97 & $72.33 \pm 3.08$ & 0.67 \\
\hline & Green tea & $81.66 \pm 4.95$ & 0.89 & $68.76 \pm 1.65$ & 0.60 \\
\hline \multirow{15}{*}{$\begin{array}{l}\text { Herbal } \\
\text { Teas }\end{array}$} & Indian Gooseberry & $23.42 \pm 1.66$ & 0.12 & $26.42 \pm 0.67$ & 0.14 \\
\hline & Bael fruit & $14.39 \pm 4.40$ & 0.07 & $14.61 \pm 0.23$ & 0.07 \\
\hline & Bitter Cucumber & $21.87 \pm 2.67$ & 0.11 & $14.34 \pm 3.89$ & 0.07 \\
\hline & Chrysanthemum & $26.44 \pm 0.77$ & 0.14 & $21.84 \pm 3.75$ & 0.11 \\
\hline & Rosella & $19.05 \pm 2.81$ & 0.10 & $9.20 \pm 2.56$ & 0.04 \\
\hline & Saffower & $28.75 \pm 1.67$ & 0.16 & $16.69 \pm 0.40$ & 0.08 \\
\hline & Pandanus & $60.45 \pm 4.30$ & 0.47 & $48.20 \pm 3.79$ & 0.32 \\
\hline & Stevia & $19.47 \pm 4.23$ & 0.10 & $0.53 \pm 0.75$ & 0.00 \\
\hline & Jiaogulan & $19.64 \pm 3.37$ & 0.10 & $0.93 \pm 1.22$ & 0.00 \\
\hline & Asiatic Pennywort & $8.56 \pm 1.15$ & 0.04 & $0.78 \pm 1.41$ & 0.00 \\
\hline & Cat's Whiskers & $7.14 \pm 0.25$ & 0.03 & $3.30 \pm 3.70$ & 0.01 \\
\hline & White Mulberry & $9.36 \pm 4.53$ & 0.04 & ND & ND \\
\hline & Jewel Vine & $23.60 \pm 4.16$ & 0.12 & $35.17 \pm 3.77$ & 0.20 \\
\hline & Lemon Gass & $11.12 \pm 2.65$ & 0.05 & $8.68 \pm 0.25$ & 0.04 \\
\hline & Ginger & $5.67 \pm 2.29$ & 0.03 & $42.47 \pm 2.59$ & 0.27 \\
\hline
\end{tabular}

*Concentration of tea infusion in the assay $=2 \mathrm{mg} / \mathrm{mL}, \mathrm{ND}=$ not detected

Eserine eq. $=$ Eserine equivalent was calculated from the eserine inhibitory $\left(\mathrm{IC}_{50}\right)$ plot. 


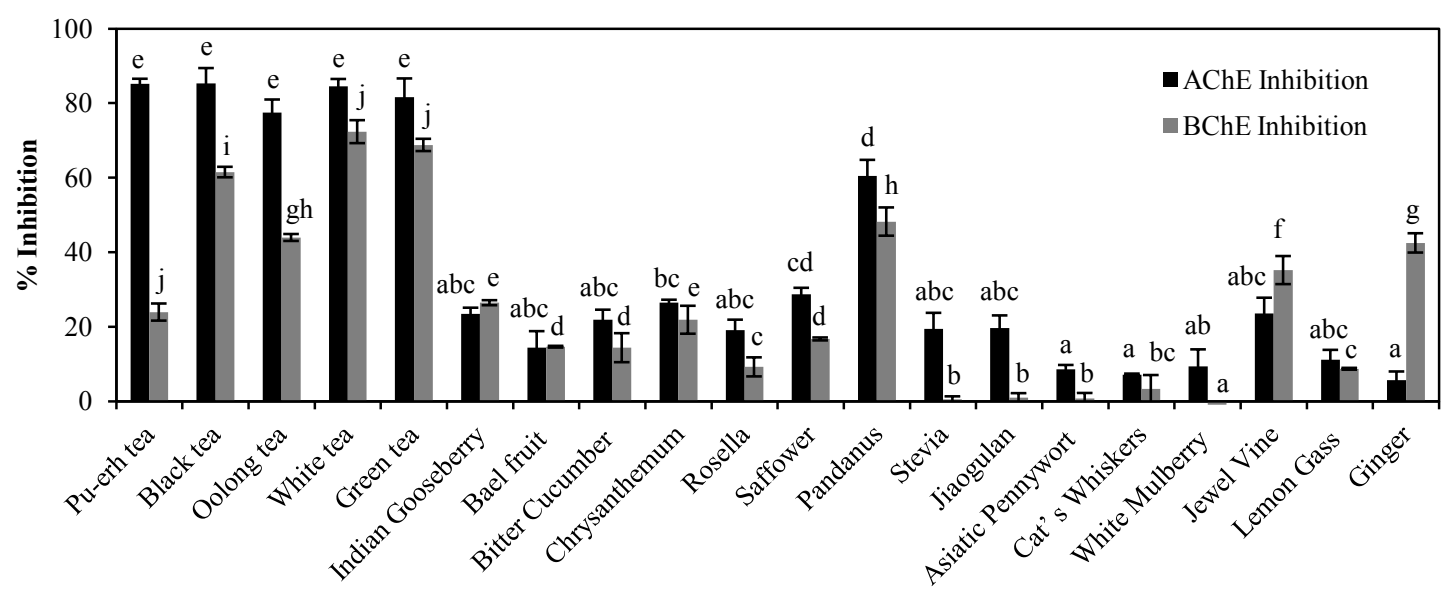

Figure 3 The AChE and BChE inhibitory activities of Camellia sinensis teas and Thai herbal teas. The different letters showed statistically significant difference of each enzyme reaction at $p$ value $<0.05$ using one-way ANOVA and Duncan's Multiple Range Test.

Interestingly, this is the first report on anti-ChEs activity of pandan tea, which was even higher than the inhibitory activity of some conventional teas and ginger tea. Ginger had been previously reported as a good anti-AD source by many previous research groups [12-14]. Rungsaeng et al. previously reported that among 15 Zingiberaceae plants, phosphate-buffered saline extract of Zingiber officinale Roscoe (fresh sample) was one of the 9 plants with high AChE inhibitory activity $\left(\mathrm{IC}_{50}\right.$ of $\left.22.4 \mu \mathrm{g} / \mathrm{mL}\right)$ [15]. Likewise, Mathew and Subramanian, 2014 reported that methanolic extracted Zingiber officinale Roscoe (dry powder) exhibited anti-AChE activity with the $\mathrm{IC}_{50}$ of $41 \mu \mathrm{g} / \mathrm{mL}$ [16], while Oboh et al., 2012 suggested that its aqueous extract (fresh sample) exhibited the $\mathrm{IC}_{50}$ of $2.86 \mathrm{mg} / \mathrm{mL}$ [17]. From these results, types of sample and extraction conditions are considered as significant external factors, which greatly affect AChE inhibitory activity. Rungsaeng et al. also suggested that other than reported phytochemicals (flavonoids, tannins, alkaloids and terpenoids) detected in ginger [18,19], short chain peptides (16 amino acids presumably from zingipain-1 and 9 amino acids presumably from actinidin Act 2a) could act as AChE non-competitive inhibitors with the $K_{i}$ value of approx. $9.3 \mathrm{mg} / \mathrm{mL}$ [15]. It was also observed that these short chain peptides were less effective against AChE than phytochemicals [15].

In attempt to explain inhibitory activity of pandan leaves, its phenolic acids and flavonoids were preliminary investigated using HPLC analysis. As results, we found that pandan leaves contained higher contents of total flavonoids (approx. 1.6 times) than phenolic acids (data not shown). Flavonoids of pandan consisted of quercetin and kaempferol (the content of quercetin was approximately. 1.2 times higher than kaempferol), while its phenolic acids consisted of caffeic acid, $p$-coumaric acid and sinapic acid (data not shown). Zhao et al. previously reported that quercetin with the $\mathrm{IC}_{50}$ of $15.4 \mu \mathrm{g} / \mathrm{mL}$ against AChE [20] had been proven to be effective against P19-derived neuronal (embryonic carcinoma) cells, in which it could enhance cell survival and induce neurite outgrowth [21]. Kaempferol was previously reported to exhibit higher $\mathrm{IC}_{50}(37 \mu \mathrm{g} / \mathrm{mL}$ against $\mathrm{AChE}$ [20]) than quercetin, suggesting that quercetin is a more effective AChE inhibitor than kaempferol. Phenolic acids, on the other hand, were potentially less effective against AChE than flavonoids [22,23].

\section{$\beta$-Amyloid inhibitory activity}

Since pandan tea exhibited the highest anti-ChEs activities among all investigated herbal teas (and in $\mathrm{BChE}$ case, the inhibition was even greater than those of some conventional teas), it was of interest to continuingly investigate its other perspectives toward neuroprotective effect. Accumulation of overproduced $\beta$-amyloid in hippocampus and other areas of the cerebral cortex are hypothesized as one 
http://wjst.wu.ac.th

cause of $\mathrm{AD}$ occurrence. The $\beta$-amyloid is the peptide with $36-43$ amino acids, which is generated from long chain protein, APP (695-770 amino acids), by proteolytic BACE1 [24]. This phenomenon was supported by the previous study by Anand and Singh [25], which indicated that inhibition of BACE1 activity in mice could lead to less $\beta$-amyloid production. To investigate anti-BACE1 activity, water extract of pandan leaves was prepared instead of pandan tea infusion, since future food applications on pandan leaves can gain more benefits from this research. As result, it was found that pandan leaves extract exhibited anti-BACE1 activity with $98 \%$ inhibition (the extract at $2 \mathrm{mg} / \mathrm{mL}$ ), suggesting its potential neuroprotective effect against $\mathrm{AD}$ through prevention of $\beta$-amyloid formation.

Climbing defected analysis

To confirm a neuroprotective function regarding $\mathrm{AD}$ of pandan leaves in vivo, Drosophila expressing human amyloid beta-42 in the brain area were used as an experimental model. The climbing ability was used to study the Drosophila behavior, since age-dependent deterioration in locomotors is found in neurodegenerative diseases including $\mathrm{AD}$ [26]. This trans-heterozygous AD flies were formerly used as a neurodegenerative model of $\mathrm{AD}$ [27]. Elav/AD flies were treated with deionized water (a solvent control), donepezil (an AD drug) and pandan extract. The Elav flies were also included as an ADfree control. At day 7, 14 and 21, flies were tested for their ability to climb, and climbing index was subsequently calculated. As result, the Elav flies showed the highest ability to climb compared to Elav/AD flies (AD flies) exposed to deionized water (Figure 4). Moreover, the climbing ability of Elav/AD flies was gradually decreased by fly's age, which represented human AD pathogenesis. The Elav/AD flies exposed to donepezil did not show any climbing defect from amyloid-42 toxicity, confirming its ability as AD drug as previously reported by Liu et al. [28]. Interestingly, pandan leaves extract was able to prevent and reduce amyloid-42 toxicity as donepezil at the indicated day, suggesting the ability of pandan in prevention of $\mathrm{AD}$ in vivo. In addition, this study implied that pandan leaves extract may pass blood-brain barrier through the Drosophila brain.

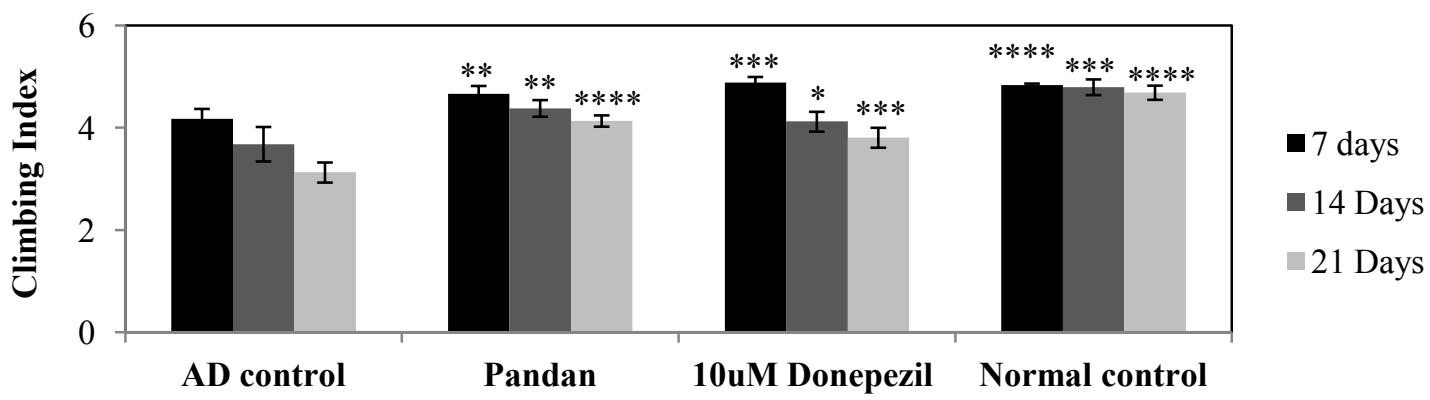

Figure 4 The climbing defect assay using AD Drosophila melanogaster model. The different numbers of star showed statistically significant difference at $p$ value $<0.05$ using t-test.

\section{Conclusions}

The optimized assay conditions for cholinesterase indicated that the appropriate substrate concentrations (0.08 mM ATCh and $0.1 \mathrm{mM} \mathrm{BTCh)} \mathrm{and} \mathrm{enzyme} \mathrm{concentrations} \mathrm{(10} \mathrm{-} 30 \mathrm{ng}$ AChE and 10 - $50 \mathrm{ng} \mathrm{BChE}$ ). The reaction time was varied according to the enzyme and substrate concentrations. Under these optimized conditions, conventional and pandan tea infusions showed high ChEs inhibitory activities. Thus, these tea infusions could be used as effective anti-AD beverages. Pandan leaves extract was further investigated regarding termination of beta-amyloid formation both in in vitro and in vivo experiments. It was found that pandan leaves extract exhibited high in vitro anti-BACE1 activity, while in vivo Drosophila melanogaster study suggested the ability of pandan leaves in AD prevention. 
http://wjst.wu.ac.th

Furthermore, the development and investigation of anti-Alzheimer's agents as potential nutraceuticals or drugs are highly possible for pandan leaves.

\section{Acknowledgements}

The financial support of this research was received from the graduate scholarship of the National Research Council of Thailand, 2013.

\section{References}

[1] A Tripathi and UC Srivastava. Acetylcholinesterase: A versatile enzyme of nervous system. Ann. Neurosci. 2008; 15, 106-110.

[2] DM Bowen, CB Smith, P White and AN Davision. Neurotransmitter-related enzymes and indices of hypoxia in semile dementia and other abiotrophies. Brain Res. 1976; 99, 459-96.

[3] M Pakaski, M Hugyecz, P Santha, G Jancso, A Bjelik, A Domokos, Z Janka and J Kálmán. Capsaicin promotes the amyloidogenic route of brain amyloid precursor protein processing. Neurochem. Int. 2009; 54, 426-30.

[4] NH Greig, T Utsuki, DK Ingram, Y Wang, G Pepeu, C Scali, QS Yu, J mamczarz, HW Holloway, T Giordano, DM Chen, K Furukawa, K Sambamurti, A Brossi and DK Lahiri. Selective butyrylcholinesterase inhibition elevates brain acetylcholine, augments learning and lowers Alzheimer $\beta$-amyloid peptide in rodent. Proc. Natl. Acad. Sci. USA 2005; 102, 17213-8.

[5] SA Mandel, T Amit, O Weinreb, L Reznichenko and MB Youdim. Simultaneous manipulation of multiple brain targets by green tea catechins: A potential neuroprotective strategy for Alzheimer and Parkinson diseases. CNS Neurosci. Ther. 2008; 14, 352-65.

[6] EJ Okello, SU Savelev and EK Perry. In vitro anti-beta-secretase and dual anti-cholinesterase activities of Camellia sinensis L. (tea) relevant to treatment of dementia. Phytother. Res. 2004; 18, 624-7.

[7] GL Ellman, KD Courtney and RM Featherstone. A new and rapid colorimetric determination of acetylcholinesterase activity. Biochem. Pharmacol. 1961; 7, 88-95.

[8] AH Jung, BS Min, T Yokozawa, JH Lee, YS Kim and JS Choi. Anti-Alzheimer and antioxidant activities of Coptidis Rhizoma alkaloids. Biol. Pharm. Bull. 2009; 32, 1433-8.

[9] S Jantrapirom, LL Piccolo, H Yoshida and M Yamaguchi. A new Drosophila model of Ubiquilin knockdown shows the effect of impaired proteostasis on locomotive and learning abilities. Exp. Cell Res. 2018; 362, 461-71.

[10] SM Karori, FN Wachira, JK Wanyoko and RM Ngure. Antioxidant capacity of different types of tea products. Afr. J. Biotechnol. 2007; 6, 2287-96.

[11] M Monczor. Diagnosis and treatment of Alzheimer's disease. Cent. Nerv. Syst. Agents Med. Chem. $2005 ; 5,5-13$.

[12] G Oboh, AJ Akinyemi and AO Ademiluyi. Antioxidant and inhibitory effect of red ginger (Zingiber officinale var. Rubra) and white ginger (Zingiber officinale Roscoe) on $\mathrm{Fe}(2+)$ induced lipid peroxidation in rat brain in vitro. Exp. Toxicol. Pathol. 2012; 64, 31-6.

[13] S Maralla and KS Reddy. Effect of aqueous extract of ginger on acetylcholine in brain and its possible role in learning and memory during ethanol withdrawal. Asian J. Pharm. Clin. Res. 2014; 7, 192-8

[14] BT Tung, DK Thu, NTK Thu and NT Hai. Antioxidant and acetylcholinesterase inhibitory activities of ginger root (Zingiber officinale Roscoe) extract. J. Compl. Integr. Med. 2017; 14, 20160116.

[15] P Rungsaeng, P Sangvanich and A Karnchanatat. Zingipain, a ginger protease with acetylcholinesterase inhibitory activity. Appl. Biochem. Biotechnol. 2013; 170, 934-50.

[16] M Mathew and S Subramanian. In vitro evaluation of anti-Alzheimer effects on dry ginger (Zingiber officinale Roscoe) extract. Indian J. Exp. Biol. 2014; 52, 606-12. 
http://wjst.wu.ac.th

[17] G Oboh, AO Ademiluyi and AJ Akinyemi. Inhibition of acetylcholinesterase activities and some pro-oxidant induced lipid peroxidation in rat brain by two varieties of ginger (Zingiber officinale). Exp. Toxicol. Pathol. 2012; 64, 315-9.

[18] H Tohma, İ Gülçin, E Bursal, AC Gören, SH Alwasel and E Köksal. Antioxidant activity and phenolic compounds of ginger (Zingiber officinale Rosc.) determined by HPLC-MS/MS. Food Meas. 2017; 11, 556-66.

[19] S Mošovská, D Nováková and M Kaliňák. Antioxidant activity of ginger extract and identification of its active components. Acta Chim. Slov. 2015; 8, 115-9.

[20] Y Zhao, J Dou, T Wu and HA Aisa. Investigating the antioxidant and acetylcholinesterase inhibition activities of Gossypium herbaceam. Molecules 2013; 18, 951-62.

[21] N Tangsaengvit, W Kitphati, S Tadtong, N Bunyapraphatsara and V Nukoolkarn. Neurite outgrowth and neuroprotective effects of quercetin from Caesalpinia mimosoides Lamk. on cultured P19derived neurons. Evid. Based Compl. Alternat. Med. 2013; 2013, 838051.

[22] D Szwajgier. Anticholinesterase activity of phenolic acids and their derivatives. Z. Naturforsch C $2013 ; \mathbf{6 8}, 125-32$.

[23] I Orhan, M Kartal, F Tosun and B Şener. Screening of various phenolic acids and flavonoid derivatives for their anticholinesterase potential. Z. Naturforsch 2007; 62, 829-32.

[24] AP Huovila, AJ Turner, M Pelto-Huikko, I Karkkainen and RM Ortiz. Shedding light on ADAM metalloproteinases. Trends Biochem. Sci. 2005; 30, 413-22.

[25] P Anand and B Singh. Flavonoids as lead compounds modulating the enzyme targets in Alzheimer's disease. Med. Chem. Res. 2013; 22, 3061-75.

[26] X Wang, JR Kim, SB Lee, YJ Kim, MY Jung, HW Kwon and YJ Ahn. Effects of curcuminoids identified in rhizomes of Curcuma longa on BACE-1 inhibitory and behavioral activity and lifespan of Alzheimer's disease Drosophila models. BMC Compl. Alternat. Med. 2014; 14, 88.

[27] C Breda, KV Sathyasaikumar, SS Idrissi, FM Notarangelo, JG Estranero, GGL Moore, EW Green, CP Kyriacou, R Schwarcz and F Giorgini. Tryptophan-2,3-dioxygenase (TDO) inhibition ameliorates neurodegeneration by modulation of kynurenine pathway metabolites. Proc. Natl. Acad. Sci. USA 2016; 113, 5435-40.

[28] QF Liu, JH Lee, YM Kim, S Lee, YK Hong, S Hwang, Y Oh, K Lee, HS Yun, IS Lee, S Jeon, YW Chin, BS Koo and KS Cho. In vivo screening of traditional medicinal plants for neuroprotective activity against A $\beta 42$ cytotoxicity by using Drosophila models of Alzheimer's disease. Biol. Pharm. Bull. 2015; 38, 1891-901. 